\title{
Synedra sp. sebagai Mikroalga yang Ditemukan di Sungai Besuki Porong Sidoarjo, Jawa Timur
}

\author{
DINA ISTI'ANAH*, MOCH. FAIZUL HUDA, AINUN NIKMATI LAILY \\ Jurusan Biologi, Fakultas Sains dan Teknologi, Universitas Islam Negeri Maulana Malik Ibrahim Malang \\ Jl. Gajayana 50, Malang, Indonesia \\ *email: dina.istianah@gmail.com
}

Manuscript received: 16 Desember 2014 Revision accepted: 26 Januari 2015

\begin{abstract}
Microalgae in Sidoarjo Porong River is one component that can be used as bio-indicators of an imbalance in the ecosystem due to pollution load. Since the end of 2009, the River Porong Sidoarjo mud flow of water into which further aggravate the pollutant load to the Porong River. Water disposal Sidoarjo mud into the Porong River is thought to cause changes in the quality or increase water pollution. This study aims to determine phytoplankton found and to know the status of pollution in the river Besuki Porong Sidoarjo. Sampling was performed twice microalgae by using a plankton net and without plankton net or directly in September 2014. The results showed that the kind of microalgae found Synedra sp. The River Porong Sidoarjo. Synedra sp. is a type of algae from Chrysophyceae division that can live in almost every aquatic environment enough sunlight to sustain its activities. Environmental factors were measured at the time of sampling are: light intensity of 251 lux, the $\mathrm{pH}$ of 8 , the water temperature was $29^{\circ}$, and the air temperature at $32^{\circ} \mathrm{C}$.
\end{abstract}

Keywords: Mikroalga, Synedra sp., Sungai Besuki Porong Sidoarjo

\section{LATAR BELAKANG}

Kondisi suatu wilayah pesisir erat kaitannya dengan sistem suatu sungai yang bermuara di wilayah itu. Oleh karena itu wilayah pesisir secara alami merupakan bagian yang tidak terpisahkan dari suatu sistem aliran sungai (Supriharyono, 2007). Pesisir Sidoarjo secara umum dialiri sejumlah sungai seperti salah satunya adalah sungai Besuki Porong. Masukan material dan nutrien dari sungaisungai tersebut menyebabkan perlunya pengelolaan wilayah pesisir Sidoarjo secara serius.

Terkait dengan permasalahan tersebut, maka pengelolaan pesisir Sidoarjo menjadi sangat penting. Seperti halnya pentingnya daerah pesisir pada umumnya, muara sungai yang juga merupakan bagian daerah pesisir yang memainkan peranan penting secara ekonomi, secara ekologi dan juga merupakan kawasan dengan ekosistem komplek (Dahuri, 2004).

Sungai merupakan suatu bentuk ekosistem aquatik yang mempunyai peran penting dalam daur hidrologi dan berfungsi sebagai daerah tangkapan air (catchment area) bagi daerah sekitarnya, sehingga kondisi suatu sungai sangat dipengaruhi oleh karakteristik yang dimiliki oleh lingkungan sekitarnya (Suwondo dkk, 2004). Lingkungan perairan sungai terdiri dari komponen abiotik dan biotik yang saling berinteraksi melalui arus energi dan daur hara. Bila interaksi keduanya terganggu maka akan terjadi perubahan yang menyebabkan ekosistem perairan itu menjadi tidak seimbang (Ferianita, 2008).

Bahkan sejak munculnya lumpur panas Sidoarjo di Kecamatan Porong tanggal 29 Mei 2006 dengan luapan lumpur antara 120.000 sampai $130.000 \mathrm{~m}^{3}$ setiap harinya, turut memperparah beban Sungai Porong terhadap polutan atau pencemaran dimana sejak akhir tahun 2009 air lumpur dialirkan ke Sungai Porong. Pembuangan air lumpur panas Sidoarjo ke Sungai Porong diduga akan menyebabkan perubahan kualitas atau peningkatan pencemaran perairan (Ferianita, 2008).

Keberadaan fitoplankton dapat dijadikan sebagai bioindikator adanya perubahan kualitas lingkungan perairan yang disebabkan ketidakseimbangan suatu ekosistem akibat beban pencemaran. Hal tersebut dapat dilihat berdasarkan keberadaan jenis fitoplankton yang mendominasi di perairan tersebut (Ferianita, 2008).

Penelitian ini bertujuan untuk mengetahui fitoplankton yang ditemukan serta mengetahui status pencemaran di Sungai Besuki Porong Sidoarjo.

\section{METODE}

\section{Waktu dan Tempat}

Penelitian tentang Synedra sp. sebagai Mikroalga yang Ditemukan di Sungai Besuki Porong Sidoarjo, Jawa Timur dilaksanakan pada bulan September 2014 di Sungai Besuki Porong Sidoarjo.

\section{Alat dan Bahan}

Alat dan bahan yang dibutuhkan untuk mendukung penelitian tentang Synedra sp. sebagai Mikroalga yang Ditemukan di Sungai Besuki Porong Sidoarjo adalah 1 buah plankton net, 1 buah sprayer, 1 buah corong gelas, 1 Buah Mikroskop Binokuler, 2 Buah Objek glass, 2 Buah deckglass 1 buah water sampler, 1 buah labu ukur, 1 buah pipet tetes plastik, 2 buah botol plastik berukuran $250 \mathrm{ml}$, 
2 buah botol plastic berukuran 1 liter, 2 buah tabung film, 30 tetes Formalin 4\% dan Aquades $250 \mathrm{ml}$.

\section{Prosedur Penelitian}

Prosedur penelitian tentang Synedra sp. sebagai Mikroalga yang Ditemukan di Sungai Porong Sidoarjo dengan menggunakan tiga tahapan.

Tahap pertama yakni, tahap persiapan pengambilan air dengan water sampler. Tahap ini dilakukan dengan cara disiapkan alat dan bahan yang digunakan penelitian pada sampel kemudian diambil air sungai dengan menggunakan water sampler setelah itu dituangkan air water sampler ke dalam plankton net dan ditunggu hingga air habis. Selanjutnya diletakkan mesh plankton diatas corong gelas dan labu ukur, disemprot mesh plankton net dengan menggunakan sprayer berisi aquades, ditambahkan aquades sampai $250 \mathrm{ml}$ dan dikocok sampai homogen serta ditetesi dengan formalin $4 \%$ sebanyak 5 tetes.

Tahap kedua yakni tahap persiapan pengambilan air secara langsung. Tahap ini dilakukan dengan cara disiapkan alat dan bahan yang digunakan penelitian pada sampel kemudian diambil air sungai dengan botol plastic sebanyak 1 liter dan ditetesi dengan formalin $4 \%$ sebanyak 25 tetes.

Tahap ketiga yakni tahap analisis. Hal-hal yang dilakukan pada tahap ini adalah dengan disiapakan Alat dan Bahan pengamatan selanjutnya dinyalakan mikroskop, diambil sampel satu tetes ke atas objek glass dan ditutup deck glass dan diamati sampel dari perbesaran terkecil hingga terbesar serta diambil gambar pengamatan.

\section{HASIL DAN PEMBAHASAN}

Sungai Besuki porong sidoarjo merupakan jenis sungai yang bisa dijadikan bioindikator adanya perubahan kualitas lingkungan perairan yang disebabkan ketidakseimbangan suatu ekosistem akibat beban pencemaran.

Berdasarkan hasil pengamatan yang dilakukan didapatkan hasil yakni intensitas cahaya sebesar 251 lux, pH sebesar 8, Suhu Air sebesar $29^{\circ} \mathrm{C}$ dan Suhu Lingkungan sebesar $32{ }^{\circ} \mathrm{C}$. intensitas cahaya, $\mathrm{pH}$, Suhu Air dan Suhu Lingkungan merupakan faktor-faktor abiotik yang mempengaruhi struktur komunitas fitoplankton di daerah sungai Besuki porong Sidoarjo.

Tabel 1. Data Hasil Penelitian

\begin{tabular}{ccc}
\hline No & Identifikasi & Keterangan \\
\hline 1. & Intensitas Cahaya & 251 lux \\
2. & Suhu Air & $29{ }^{\circ} \mathrm{C}$ \\
3. & Ph & 8 \\
4. & Suhu Lingkungan & $32^{\circ} \mathrm{C}$ \\
\hline
\end{tabular}

Sampling dilakukan dengan mengambil 2 titik yang terletak di pinggir Sungai Porong Besuki Sidoarjo. Jarak antara titik satu dengan titik yang lain sekitar $10 \mathrm{~m}$. Pengambilan sampling dilakukan pada kondisi air Sungai yang sedikit keruh.

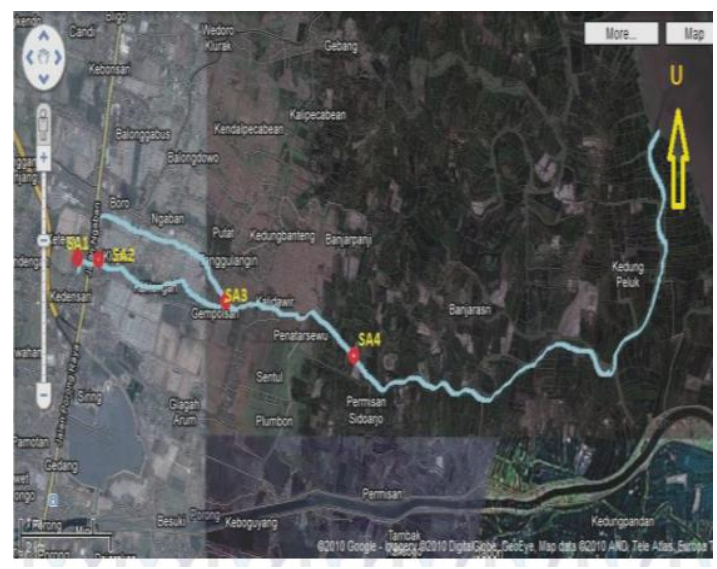

Gambar 1. Lokasi Pengambilan Sampel di Sungai Besuki, Sidoarjo

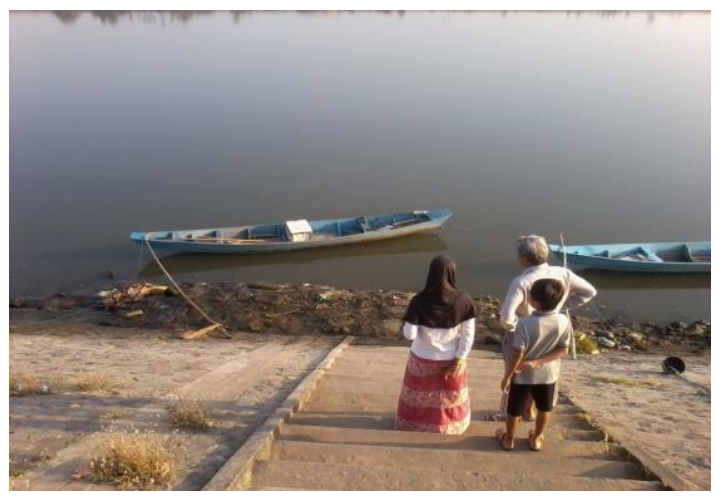

Gambar 2. Lokasi Sungai Besuki Porong Sidoarjo

\section{Synedra sp. Sebagai Bioindikator Kondisi Lingkungan Perairan Sungai Besuki}

Keanekaragaman Cyanophyceae di suatu perairan dapat dijadikan bioindikator dalam memonitoring kualitas air. Apabila dalam suatu perairan didominasi oleh spesies dari kelas Cyanophyceae atau alga biru hijau, maka perairan tersebut dapat diindikasikan adanya pencemaran (Lee, 2006). Salah satu contoh dari kelas Cyanophyceae adalah Synedra sp., dimana dominansi dari golongan Synedra sp. ini dapat dijadikan indikasi turunnya kualitas air (pencemaran) (Rangpan, 2008).

Hasil penelitian menunjukkan bahwa Sungai Besuki Porong Sidoarjo perairan dalam kondisi tercemar ringan. Dimana kelimpahan fitoplankton di Sungai Besuki didominasi oleh golongan Synedra sp.. Hasil ini diperkuat oleh Rangpan (2008) yang menjelaskan bahwa Synedra $s p$. ditemukan mendominasi pada perairan dalam kondisi tercemar ringan dan Synedra sp. juga mampu hidup pada kondisi DO yang rendah.

Kelompok dari jenis kelas Bacillariophyceae ini dapat ditemukan hampir disetiap lingkungan perairan yang cukup sinar matahari untuk mempertahankan aktivitas. Synedra. sp mempunyai kelimpahan yang tinggi dan dapat ditemukan di berbagai habitat misalnya tanah basah, dinding batu, karang terjal, gambut, dan kulit kayu. Juga dapat dilihat sebagai buih kuning diatas lumpur pada 
selokan atau kolam. Beberapa diatom hidup sebagai epifit pada alga lain atau tanaman liar (Sulisetijono, 2009).

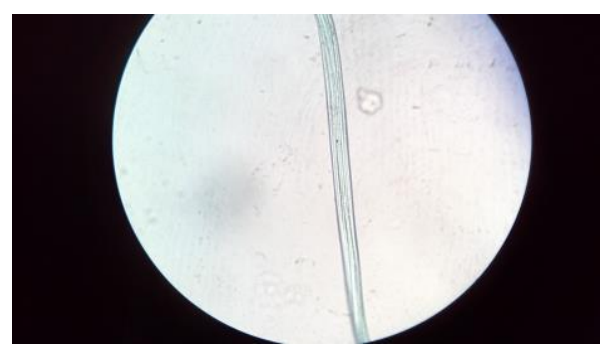

Gambar 3. Synedra sp. yang ditemukan

Menurut Estiati (1995), Alga jenis Synedra sp. memiliki klasifikasi sebagai berikut:

$\begin{array}{ll}\text { Regnum } & \text { : Plantae } \\ \text { Divisio } & \text { : Thallophyta } \\ \text { Subdivisio } & \text { : Algae } \\ \text { Classis } & \text { : Bacillariophyceae } \\ \text { Ordo } & \text { : Pennales } \\ \text { Familia } & \text { : fnigillariaceae } \\ \text { Genus } & \text { : Synedra } \\ \text { Spesies } & : \text { Synedra } s p .\end{array}$

Synedra sp. juga diketahui memiliki kemampuan bertahan terhadap perubahan kondisi lingkungan yang tidak menguntungkan. Hal ini dimungkinkan karena Synedra sp. memiliki bentuk yang diatom, sehingga memiliki sel pembungkus yang berlapis (Conradie, 2008).

Selain itu Synedra sp. juga mampu bertahan dalam lingkungan yang rendah nutrisi (oligotrifik) dengan konsentrasi nitrogen dan phospat rendah. Hal ini dikarenakan Synedra sp. mampu mengakumulasi nutrisi dan menyimpannya sebagai cadangan makanan dalam bentuk polimer yang tidak terlarut (Venter, 2003).

\section{KESIMPULAN}

Kesimpulan yang didapatkan pada Penelitian tentang Synedra sp. sebagai Mikroalga yang Ditemukan di Sungai Besuki Porong Sidoarjo, Jawa Timur adalah :

Fitoplankton yang mendominasi di perairan Sungai Besuki adalah Synedra sp..

Dengan adanya Synedra sp. dapat dikatakan bahwa Sungai Besuki Porong Sidoarjo dalam kondisi tercemar ringan.

Pada penelitian ini perlu diadakan penelitian lebih lanjut mengenai kepadatan fitoplankton yang ditemukan di Sungai Besuki Porong Sidoarjo.

\section{UCAPAN TERIMA KASIH}

Penelitian ini terselesaikan dengan adanya bantuan moril maupun materil dari berbagai pihak, sehingga dengan hormat peneliti mengucapkan terima kasih yang sebesarbesarnya kepada Ibu Ainun Nikmati Laily, M.Si selaku dosen pembimbing dalam menyelesaikan penelitian ini serta pihak yang telah membantu terselesaikannya penelitian ini.

\section{DAFTAR PUSTAKA}

Conradie,K.R.; S. Du Plessis and A. Venter. 2008. School of Environmental Sciences and Development: Botany. South Africa. South African Journal of Botany 74 (2008) 101-110.

Dahuri, R. Rais, J., Sapta, P.G. Sitepu. (2004), Pengelolaan Sumberdaya Wilayah Pesisir dan Laut Secara Terpadu, Cetakan ke -3. PT. Pradnya Paramita. Jakarta

Estiati B, Hidayat. 1995.Taksonomi tumbuhan (Cryptogamae). Bandung : ITB Press

Ferianita, Melati - Fachrul; Setijati Hartinah E., dan Monika Wulandari. Komposisi dan Model Kelimpahan Fitoplankton di Perairan Sungai Ciliwung, Jakarta. Universitas Trisakti. Jakarta

Rangpan, Vichit. 2008. Effects of Water Quality on Periphyton in The Pattani River, Yala Municipality, Thailand. Thesis Submitted in Fulfillment of The Requirements For The Degree of Doctor of Philosophy, Universitas Sains Malaysia. Malaysia

Sabithah,S. 1999. Taksonomi Tumbuhan I (ALGAE). Yogyakarta : UGM Press

Sulisetjono. 2009. Bahan Serahan Alga. Malang : UIN Malang Press

Supriharyono, (2007), Konservasi Ekosistem Sumberdaya Hayati di Wilayah Pesisir dan Laut Tropis. Pustaka Pelajar. Yogyakarta.

Suwondo, Elya Febrita, Dessy dan Mahmud Alpusari. 2004. Kualitas Biologi Perairan Sungai Senapelan, Sago dan Sail di Kota Pekanbaru Berdasarkan Bioindikator Plankton dan Bentos. Universitas Riau. Pekanbaru.

Venter, A. A Jordaan and AJH Pieterse. 2003. Oscillatoria simplicissima: A taxonomical study. School of Environmental Sciences and Development: Botany. South Africa. Journal Water SA Vol. 29 No.1 